\title{
Assessing Oral Health Status, Practices, and Access to Care among War-Affected Refugees Living in San Antonio, Texas
}

\author{
Rami Saadeh ${ }^{1}$ David Cappelli² Irene Bober-Moken ${ }^{3}$ \\ ${ }^{1}$ Department of Public Health and Community Medicine, Faculty \\ of Medicine, Jordan University of Science and Technology, \\ Ar-Ramtha, Jordan \\ 2Department of Biomedical Sciences, School of Dental Medicine, \\ University of Nevada Las Vegas, Las Vegas, Nevada, United States \\ ${ }^{3}$ Department of Comprehensive Dentistry, School of Dentistry, \\ University of Texas Health Sciences Center at San Antonio, \\ San Antonio, Texas, United States
}

Eur J Dent:2020;14:371-379

\author{
Annaliese Cothron ${ }^{3}$ Magda de la Torre ${ }^{3}$
}

\begin{abstract}
Keywords

- refugees

- San Antonio

- oral health status

- oral health practices

- oral health access

Objectives Refugees encounter several health disparities including oral health problems. This study evaluated the self-reported oral health status, practices, and access to care of adult refugees living in San Antonio, Texas, United States.

Materials and Methods Adult refugees $(n=207)$ who accessed services from two centers in San Antonio, completed this survey. Multivariate logistic regression was used to examine the relationship of the refugees' demographics with oral health status, practices, and access to care.

Results Oral pain in the previous 12 months was common among refugees having been reported by almost $58.9 \%$ of the survey participants; $43 \%$ reported pain as the reason for their last dental visit. Approximately half of the participants reported both the condition to their teeth and gums as being good: 42.5 and $54.6 \%$, respectively. Most participants (84\%) reported brushing their teeth one or two times a day, and around $78 \%$ reported they never smoked. Fifty-two percent reported needing dental care in the past 12 months, but not being able to receive it; while $45.9 \%$ reported not having dental insurance, $41.5 \%$ reported not having money to pay a dentist. Fifteen percent reported never visiting a dentist. Arabic speakers, moving to the United States more recently, and lower level of education were associated with a poor oral health status and practices $(p<0.05)$.

Conclusion Refugees in this study encountered limited access to dental care. Their inability to seek dental care could affect their oral and general health, weaken efforts of preventing oral health diseases, and restrict their full inclusion into the community.
\end{abstract}

\author{
Address for correspondence Rami Saadeh, BDS, MSPH, PhD, \\ Department of Public Health and Community Medicine, Faculty \\ of Medicine, Jordan University of Science and Technology, \\ Ar-Ramtha 3030,Ar-Ramtha, Jordan (e-mail: Rasaadeh@just.edu.jo).
}

\section{Introduction}

The United States is a country of immigrants both legal and illegal. Legal immigrants fall into several categories: refugee, parolee, asylee, special immigrant visas holder, and victims of human trafficking. ${ }^{1}$ Of the approximately one million migrants lawfully entering the United States every year, less than $10 \%$ are refugees. ${ }^{2}$ In the early 21 st century, most refugees were from the Soviet Union and Southeast Asia, but more recently they are coming from Eastern Europe, 
Central Asia, Africa, and the Middle East. In the past decade, conflicts and wars increased the number of refugees from the Middle East. ${ }^{3}$

Of the refugees coming into the United States, $10 \%$ settle in Texas; the majority go to Houston, Dallas, and Fort Worth. ${ }^{4}$ Although the number of immigrants in Texas has been increasing since 2011, the percentage of those being refugees has been decreasing: $72 \%$ of 9,759 in 2012 to $46 \%$ of 15,866 in 2015. ${ }^{1}$ The largest proportion of refugees in Texas is from Iraq, Congo, and Myanmar: 7 to $8 \%$ of them reside in Bexar County. ${ }^{1}$ As of December 2015, 615 refugees were identified as living in San Antonio: most of them from Myanmar $(n=285)$ and Iraq $(n=145){ }^{4}$

Refugees are a vulnerable population with experiences of traumatic events including casualties of war, hunger, family loss, social and emotional stress, human rights violations, and physical intimidation or violence. Such circumstances impacted access to basic health services in their country of origin, including access to preventive care, oral health care, chronic disease management, and nutrition. Refugees lack an intact health care system and experience a higher prevalence of certain diseases. ${ }^{5-8}$ Therefore, refugees require access to a health care system focused on wellness that is culturally appropriate, addresses communication barriers, and is sensitive to experiences associated with traumas of war. ${ }^{9}$ Among the health care needs and treatment of diseases, oral health care is needed to address the high prevalence of dental caries, oral trauma (missing and fractured teeth), and periodontal disease. ${ }^{9}$

Studies from different countries demonstrated a difference between refugees and locals in their oral health status. For example, studies from Sweden, Holland, and Italy reported that refugees from Chile, Poland, and Yugoslavia had poorer oral health and needed more treatment than did their native citizens. ${ }^{10-13}$ In the United States, however, Cote et al assessed the oral health status of newly arrived refugee children ( 6 months-18 years) participating in the Refugee Health Assessment Program. This study found significant differences in the oral health status among different ethnic groups of refugees when compared with findings from National Health and Nutrition Examination Survey (NHANES III). ${ }^{3}$ A study in Massachusetts of Somali refugees found that English health literacy and spoken proficiency were not the main factors in the utilization of preventive care services and oral health status of refugees. However, acculturation was more predictive of care use and oral health condition. ${ }^{14,15}$

There is a limited data that examines the oral health needs of the adult refugee population in the United States. Studies are lacking that describe the oral health status, oral health care access, and health care needs of refugees, specifically refugees who are affected by war in the Middle East and in Myanmar. Therefore, this study aimed to identify selfreported oral health status, oral health practices, and oral health care access of adult refugees living in San Antonio, Texas.

\section{Materials and Methods}

This was a cross-sectional study that utilized a self-report survey collecting data from refugees affected by war who have relocated to San Antonio. A convenience sample of participants was collected at two sites that provide services to refugees: Center for Refugee Services of San Antonio and the Islamic Center of San Antonio. The Institutional Review Board (IRB) approval was obtained from the University of Texas Health Science Center at San Antonio. Letters of agreement between the two sites and the Dental Public Health Advanced Education Program at the University of Texas Health School of Dentistry were made to establish collaboration for data collection.

\section{Data Collection}

Data was collected at both sites, during routine business hours, under the supervision of the facility director or a person in charge of immigration services at each site. The survey consisted of 17 questions, including general demographic information, self-assessment of oral health status, oral health practices, and access to dental services. The first page of the survey outlined the purpose of the study, the study investigator's contact information, and a statement that completion of the survey was considered the participants' consent.

The survey was provided to refugees attending the two sites to receive services or participate in an event. The investigator did not intervene during data collection nor answer individual questions to avoid any possible bias. The completed forms were collected daily by the study investigator. Participants were informed about the purpose of the survey; upon completion of the survey, study participants received dental educational materials: a toothbrush, toothpaste, and dental floss. Oral hygiene instructions were offered to all participants, and they were given a list of dental clinics in San Antonio that provide dental care services at a reduced cost.

\section{Instrument}

The survey was developed in English and translated into the main languages of refugees: Arabic, Burmese, Persian, Pashto, Urdu, and Malaysian. Translations to other languages were provided as needed, for example, translation into Malay was done since many refugees originating in Myanmar (Burma) migrated to Malaysia before coming to the United States. All translated surveys were back-translated. Survey questions were adopted and modified from the 2013 World Health Organization's “Oral Health Surveys: Basic Methods - 5th edition." ${ }^{16}$ The use of these standardized questions helps establish comparability of data collected from different sources. The survey was pretested on 15 individuals of different languages to ensure the validity of questions and their reflection of study objectives. Pilot testing didn't show any conflict of understanding or a comment indicating a concern.

Inclusion and exclusion criteria: refugees, 18 years of age or older. Refugees who originated from a war-torn country were eligible to participate in this study. Individuals who 
were illiterate, could not read any language, or had any type of mental or cognitive disability, were excluded from this study. Participants were identified by their date of birth, language of origin, and gender to avoid duplication in data.

Demographic information: age, gender, language of origin, level of education, US education, duration in the United States were considered independent variables. Oral health status, oral health practices, and oral health care access were considered dependent variables.

\section{Analysis}

Descriptive statistics were used to examine the demographics of the refugee populations, their oral health status, oral health practices, and oral health care access. Binary logistic regression and multinomial logistic regression analyses were used to examine the relationship of demographic information with oral health status, oral health practices, and oral health care access. All variables were categorical variables except age. For the convenience of the analysis, age was categorized into three categories; 18 to 29 years old, 30 to 49 years old, and 50 years old or older. For multivariate analysis, some variables were rescaled as shown in - Table 1.

Rescaling was done because some levels of independent variables were unequally distributed across levels of dependent variables, and some were restricted in range, resulting in weak correlation and unreliable variable representation. Therefore, some levels were merged to enhance reliability of results, improve variables' representation, and minimize biases.

SPSS Statistical Software version 23 was used in the analysis, and $p$-value of 0.05 was considered statistically significant.

\section{Results}

A total of 207 refugees participated in the study: 115 males (55.6\%) and 81 females (39.1\%), as shown in - Table 2. The mean age was 37.38 years old ( \pm 12.34 years). The most common language of origin among participants was Arabic (41.5\%), followed by Persian/Dari (23.7\%). Approximately $60 \%$ of the participants had a high school education or less and $25 \%$ completed a college degree or higher. When participants were asked how long they were in the United States, 30\% had moved to the United States less than a year ago.

Tooth or mouth pain or discomfort in the past 12 months was the main oral health complaint reported by $58.9 \%$ of the participants as well as being the major reason $(43 \%)$ of the participants' visit to a dentist. As shown in - Table 3, most respondents reported the condition of their teeth or gums as "Good" (42.5 and 54.6\%, respectively); less than 10\% considered the condition of their teeth or gums as very poor.

Responses of participants show generally good oral health practices (-Table 3). Eighty-four percent of participants reported brushing their teeth once $(41.1 \%)$ or twice $(43 \%)$ on the day before the survey. Most participants reported cleaning their teeth using a toothbrush (84.5\%), toothpaste (68.6\%), and chewstick or miswak (20\%). Over one-third of the participants eat sweets (e.g., cakes or cookies) and almost one-fifth $(22.2 \%)$ reported drinking soda. However, many participants reported having two or more servings of fruits (42\%). Around three out of four participants reported to have never smoked.

While $29 \%$ of the participants reported never visiting a dentist or having seen one more than 5 years ago, just over $60 \%$ of participants reported visiting a dentist within the past 2 years. As noticed in - Table 3, almost one-fifth of the participants (18.4\%) had seen a dentist in the past 6 months. Fifty-two percent of the refugees reported needing dental care in the past 12 months, but not being able to receive it. The most common reason was financial: $45.9 \%$ reported not having dental insurance, while $41.5 \%$ reported not having money to pay a dentist. Communication issues and language barriers were issues reported by only $7.2 \%$.

Table 1 Original and modified scaling of variables used in the multivariate logistic regression

\begin{tabular}{|c|c|c|c|}
\hline Original scaling & Modified scaling & Original scaling & Modified scaling \\
\hline Language of origin & Language of origin & Condition of teeth or gums & Condition of teeth or gums \\
\hline $\begin{array}{l}\text { Arabic } \\
\text { Rohingya } \\
\text { Pashto } \\
\text { Persian/Dari } \\
\text { Other languages }\end{array}$ & $\begin{array}{l}\text { Arabic } \\
\text { Rohingya } \\
\text { Persian/Dari } \\
\text { Other languages } \\
\text { (including Pashto) }\end{array}$ & $\begin{array}{l}\text { Very good } \\
\text { Good } \\
\text { Poor } \\
\text { Very poor }\end{array}$ & $\begin{array}{l}\text { Good } \\
\text { Poor }\end{array}$ \\
\hline Education & Education & Brushing times & Brushing times \\
\hline $\begin{array}{l}\text { Less than high school } \\
\text { High school diploma } \\
\text { Some college } \\
\text { College degree } \\
\text { Postgraduate degree }\end{array}$ & $\begin{array}{l}\text { Less than high school } \\
\text { High school diploma } \\
\text { Some college } \\
\text { College degree or higher }\end{array}$ & $\begin{array}{l}\text { Did not brush } \\
\text { One time } \\
\text { Two times } \\
\text { More than two times }\end{array}$ & $\begin{array}{l}\text { Did not brush } \\
\text { One time } \\
\text { Two times or more }\end{array}$ \\
\hline Tobacco use & Tobacco use & Last visit to a dentist & Last visit to a dentist \\
\hline $\begin{array}{l}\text { Every day } \\
\text { Several times a week } \\
\text { Several times a month } \\
\text { Rarely } \\
\text { Never }\end{array}$ & $\begin{array}{l}\text { Often } \\
\text { Occasionally } \\
\text { Rarely or never }\end{array}$ & $\begin{array}{l}\text { Less than } 6 \mathrm{~m} \text { ago } \\
6-12 \mathrm{~m} \text { ago } \\
1-2 \text { y ago } \\
2-5 \text { y ago } \\
\text { More than } 5 \text { y ago } \\
\text { Never }\end{array}$ & $\begin{array}{l}0-12 \text { m ago } \\
1-2 \text { y ago } \\
2-5 \text { y ago } \\
\text { More than } 5 \text { y ago }\end{array}$ \\
\hline
\end{tabular}


Table 2 Demographic information of study participants

\begin{tabular}{|c|c|c|c|}
\hline Gender & $n(\%)$ & Age & $n(\%)$ \\
\hline Males & $115(55.6)$ & Younger than 30 y old & $51(24.6)$ \\
\hline Females & $81(39.1)$ & $30-49$ y old & $97(46.9)$ \\
\hline \multirow{2}{*}{ Unknown } & $11(5.3)$ & 50 y or older & $39(18.8)$ \\
\hline & & Unknown & $20(9.7)$ \\
\hline Education & $n(\%)$ & US education & $n(\%)$ \\
\hline Less than high school & $62(30)$ & No & $169(81.6)$ \\
\hline High school diploma or GED & $61(29.5)$ & Yes & $37(17.9)$ \\
\hline Some college & $23(11.1)$ & Unknown & $1(0.5)$ \\
\hline College degree & $47(22.7)$ & & \\
\hline Postgraduate degree & $5(2.4)$ & & \\
\hline Unknown & $9(4.3)$ & & \\
\hline Time since moved to the US & $n(\%)$ & Language & $n(\%)$ \\
\hline Less than a year ago & $63(30.4)$ & Arabic & $86(41.5)$ \\
\hline $1-2$ years ago & $47(22.7)$ & Rohingya & $23(11.1)$ \\
\hline $2-5$ years ago & $61(29.5)$ & Pashto & $30(14.5)$ \\
\hline 5 years or more ago & $32(15.5)$ & Persian/Dari & $49(23.7)$ \\
\hline Unknown & $4(1.9)$ & Other languages & $19(9.2)$ \\
\hline
\end{tabular}

\section{Multivariate Analysis}

Male respondents were less likely than females to report having tooth or mouth discomfort or pain in the previous 12 months (odds ratio [OR]: $0.45,95 \%$ confidence interval $[\mathrm{CI}]: 0.21-0.95, p=0.037$ ). Arabic speaking respondents were more likely than respondents of "other" languages to report having teeth or mouth discomfort or pain in the previous 12 months (OR: 3.92 ; 95\% CI: $1.37-11.23, p=0.011$ ). Those who relocated to the United States 1 to 2 years ago were more likely to report having teeth or mouth discomfort or pain in the previous 12 months (OR: 4.60 ; $95 \% \mathrm{CI}$ : $1.39-15.22$, $p=0.01$ ).

Regarding participants' self-reported condition of the teeth or the gums, language of origin was a strong predictor as shown in - Table 4. Education and age were also significantly associated with condition of the teeth. Those who completed less than high school of education were more likely to report poor teeth condition (OR: 3.08; 95\% CI: 1.07-8.89, $p=0.037$ ), while those in the age group of 30 to 49 were less likely to report poor teeth condition (OR: 0.28 ; 95\% CI: 0.089-0.78, $p=0.015$ ).

- Table 5 demonstrated the relationship of demographic data with time since the last visit to the dentist and reasons for that visit. Education and duration in the United States were the most statistically significant predictors. Other variables such as age and language of origin were also statistically significant. Those who moved more recently to the United States or had less education were less likely to have had seen a dentist in less than 5 years and were less likely to see a dentist for a regular checkup or consultation $(p<0.05)$. Furthermore, participants younger than 30 years old were less likely to have had seen a dentist in the previous 5 years. However, visiting a dentist for treatment or follow-up was not statistically significant $(p>0.05)$.
Although participants who arrived more recently in the United States were less likely to have had sodas in the last 24 hours than participants living in the United States for more than 5 years, and they were also less likely to have had two or more servings of fruits (-Table 6 ). The youngest age group (younger than 30 years old) was more likely to consume sweets and sodas than adults 50 years or older. Tobacco use was more common among males, individuals with less than high school of education, and Arabic speakers, as shown in - Table 6 .

Demographic data significantly associated with brushing times and brushing items, varied. Participants who moved to the United States in less than a year ago were more likely to have brushed one time than to have brushed two times or more (OR: 3.46; 95\% CI: 1.00-11.91, $p=0.049$ ). They were also less likely to use a toothpick than those who moved more than 5 years ago (OR: 0.16 ; $95 \% \mathrm{CI}: 0.032-0.78, p=0.024$ ). Participants who were 30 to 49 years old were more likely to use a toothbrush (OR: 4.02; 95\% CI: 1.16-13.9, $p=0.03$ ), and they were less likely to use a chewstick/miswak (OR: 0.19; $95 \%$ CI: $0.04-0.92, p=0.039)$ compared with participants 50 years or older. Age, gender, education levels, language, and length of time in the United States were not significantly associated with access to oral health care (i.e., needed dental care in the last 12 months in the United States but couldn't get it).

\section{Discussion}

Education level was a significant variable in this study. The majority (60\%) of refugees seeking services at the two refugee centers in San Antonio had only a high school education or less. Educational services sought in the United States were primarily English courses offered by refugees' services centers. 
Assessing Oral Health Status among War-Affected Refugees Living in San Antonio Saadeh et al. 375

Table 3 Summary of oral health status, practices, and dental care access of participants

\begin{tabular}{|c|c|c|c|c|c|}
\hline \multicolumn{2}{|l|}{ Oral health problems } & \multicolumn{2}{|l|}{ Oral health practices } & \multicolumn{2}{|l|}{ Oral health care access } \\
\hline $\begin{array}{l}\text { Discomfort or pain } \\
\text { in teeth or mouth in } \\
\text { the last } 12 \text { months }\end{array}$ & $n(\%)$ & $\begin{array}{l}\text { Brushing times, the day } \\
\text { before }\end{array}$ & $n(\%)$ & $\begin{array}{l}\text { Time since you have seen a } \\
\text { dentist }\end{array}$ & $n(\%)$ \\
\hline $\begin{array}{l}\text { Yes } \\
\text { No } \\
\text { Unknown }\end{array}$ & $\begin{array}{l}122(58.9) \\
81(39.1) \\
4(1.9)\end{array}$ & $\begin{array}{l}\text { Did not brush } \\
\text { One time } \\
\text { Two times } \\
\text { More than two times } \\
\text { Unknown }\end{array}$ & $\begin{array}{l}10(4.8) \\
85(41.1) \\
89(43) \\
21(10.1) \\
2(1)\end{array}$ & $\begin{array}{l}\text { Less than } 6 \mathrm{~m} \\
6-12 \mathrm{~m} \\
1-2 \mathrm{y} \\
2-5 \mathrm{y} \\
\text { More than } 5 \mathrm{y} \\
\text { Never }\end{array}$ & $\begin{array}{l}38(18.4) \\
37(17.9) \\
50(24.2) \\
22(10.6) \\
29(14) \\
31(15)\end{array}$ \\
\hline $\begin{array}{l}\text { Condition of your } \\
\text { teeth }\end{array}$ & $n(\%)$ & $\begin{array}{l}\text { Items used to clean } \\
\text { teeth }^{\mathrm{a}}\end{array}$ & $n(\%)$ & $\begin{array}{l}\text { Dental care was needed } \\
\text { in the past } 12 \text { months but } \\
\text { couldn't get it }{ }^{\text {b }}\end{array}$ & $n(\%)$ \\
\hline $\begin{array}{l}\text { Very good } \\
\text { Good } \\
\text { Poor } \\
\text { Very poor } \\
\text { Unknown }\end{array}$ & $\begin{array}{l}19(9.2) \\
88(42.5) \\
80(38.6) \\
18(8.7) \\
2(1)\end{array}$ & $\begin{array}{l}\text { Toothbrush } \\
\text { Toothpick } \\
\text { Thread or dental floss } \\
\text { Chewstick or miswak } \\
\text { Toothpaste }\end{array}$ & $\begin{array}{l}175(84.5) \\
29(14) \\
36(17.4) \\
42(20.3) \\
142(68.6)\end{array}$ & $\begin{array}{l}\text { Yes } \\
\text { No } \\
\text { Unknown }\end{array}$ & $\begin{array}{l}107(51.7) \\
94(45.4) \\
6(2.9)\end{array}$ \\
\hline $\begin{array}{l}\text { Condition of your } \\
\text { gums }\end{array}$ & $n(\%)$ & $\begin{array}{l}\text { Eating/drinking (past } \\
24 \text { hours) }\end{array}$ & $n(\%)$ & $\begin{array}{l}\text { Reasons for not getting } \\
\text { dental care }{ }^{\text {ab }}\end{array}$ & $n(\%)$ \\
\hline \multirow[t]{5}{*}{$\begin{array}{l}\text { Very good } \\
\text { Good } \\
\text { Poor } \\
\text { Very poor }\end{array}$} & $\begin{array}{l}20(9.7) \\
113(54.6) \\
61(29.5) \\
13(6.3)\end{array}$ & $\begin{array}{l}\text { Sweets/sugary foods } \\
\text { Candies } \\
\text { Sodas } \\
\text { Other sugar- } \\
\text { sweetened beverages } \\
\text { Two or more servings } \\
\text { of fruit }\end{array}$ & $\begin{array}{l}74(35.7) \\
35(16.9) \\
46(22.2) \\
72(34.8) \\
87(42)\end{array}$ & $\begin{array}{l}\text { No transportation } \\
\text { No dental insurance } \\
\text { No money to pay the dentist } \\
\text { Didn't know how to find a } \\
\text { dentist } \\
\text { Previous bad experiences } \\
\text { Communication problems } \\
\text { Other reasons }\end{array}$ & $\begin{array}{l}14(6.8) \\
95(45.9) \\
86(41.5) \\
12(5.8) \\
15(7.2) \\
15(7.2) \\
5(4.2)\end{array}$ \\
\hline & & Tobacco use & $n(\%)$ & & \\
\hline & & $\begin{array}{l}\text { Every day } \\
\text { Several times a week } \\
\text { Several times a month } \\
\text { Rarely } \\
\text { Never } \\
\text { Unknown }\end{array}$ & $\begin{array}{l}16(7.7) \\
10(4.8) \\
2(1) \\
15(7.2) \\
161(77.8) \\
3(1.5)\end{array}$ & & \\
\hline & & $\begin{array}{l}\text { Reason for last visit to } \\
\text { the dentist }^{\mathrm{a}}\end{array}$ & $n(\%)$ & & \\
\hline & & $\begin{array}{l}\text { Pain with teeth, gums, } \\
\text { or mouth } \\
\text { Treatment or } \\
\text { follow-up treatment } \\
\text { Regular checkup or } \\
\text { consultation } \\
\text { Prevention or dental } \\
\text { cleaning }\end{array}$ & $\begin{array}{l}90(43.5) \\
31(15) \\
15(7.2) \\
46(22.2)\end{array}$ & & \\
\hline
\end{tabular}

aMore than one reason may apply.

'Those who answered "no" to this question were asked to skip "reasons for not getting dental care."

Most of the refugees who came to the centers do so seeking "help to find a job" or "applying for government aid." There is a high possibility that many were seeking assistance because they could not find a well-paying job with their current level of education. Having a higher level of education may have assisted refugees to secure better jobs, therefore, not needing to visit the refugee center for help.

Given these factors, the findings in this study of selfreported poor oral health (condition or teeth and gums) being associated with a lower education level and language of origin (represents culture and/or ethnicity) are consistent with numerous other studies. ${ }^{10-13,17-24}$ Poor oral health status has also been associated with chronic stress, depression, and financial hardship. ${ }^{19}$ These are conditions that would be expected in a refugee population.

Another point that contributes to the condition of refugees' oral health is the time elapsed since they moved to the United States. Over $50 \%$ of participants in this 
Table 4 Relationship of demographic data with condition of the teeth and the gums of participants

\begin{tabular}{|c|c|c|c|}
\hline & $\mathrm{OR}$ & $p$-Value ${ }^{a}$ & $\mathrm{Cl}(95 \%)$ \\
\hline \multicolumn{4}{|l|}{ Condition of the teeth: poor } \\
\hline Less than high school & 3.08 & 0.037 & $(1.07-8.89)$ \\
\hline High school diploma or GED & NS & & \\
\hline Some college & NS & & \\
\hline College degree or higher & 1 & & \\
\hline Arabic & 6.23 & 0.003 & $(1.88-20.64)$ \\
\hline Rohingya & 4.8 & 0.045 & $(1.03-22.23)$ \\
\hline Persian|Dari & 4.69 & 0.014 & $(1.37-16.09)$ \\
\hline Other languages & 1 & & \\
\hline $30-49$ y old & 0.28 & \multirow[t]{2}{*}{0.015} & \multirow[t]{2}{*}{$(0.089-0.78)$} \\
\hline 50 y or older & 1 & & \\
\hline \multicolumn{4}{|l|}{ Condition of the gums: poor } \\
\hline Arabic & 5.7 & 0.01 & $(1.53-21.27)$ \\
\hline Persian|Dari & 8.5 & 0.002 & $(2.15-33.67)$ \\
\hline Other languages & 1 & & \\
\hline
\end{tabular}

Abbreviations: $\mathrm{Cl}$, confidence interval; GED, general education diploma; NS, not specified; OR, odds ratio.

Binary logistic regression was used in the analysis.

${ }^{a}$ Only significant variables are included.

"good" is the reference group for teeth and gums conditions.

sample moved to the United States in the previous 2 years. In fact, acculturation and adaptation to a new culture are less likely to occur within a short period of time, especially for those who moved at an older age. ${ }^{14,24}$ The average age of this study's participants is 37.38 years old, almost all of them have no formal US education, and lived for a short duration in the United States. Therefore, oral health practices are less likely to have changed since they moved. ${ }^{8,14}$ A study by Cruz et al revealed that adults who immigrated to the United States at an older age had higher prevalence of caries and periodontal diseases and higher treatment needs. ${ }^{25}$ The aspect that men in this study were 12 times more likely to often use tobacco than women demonstrated that acculturation was yet to occur. This is closer to the global ratio of smoking, which is five times much more common in men than in women. ${ }^{26}$ The ratio in the United States is much different. The prevalence of smoking in women is $13.5 \%$, compared with $17.5 \%$ in men, as of in $2016 .^{27}$

Although most participants had a low level of education, came to the country at an older age, and consumed a lot of sweets and sweetened beverages, they showed good oral health practices toward brushing times and items used to clean their teeth. A possible explanation for brushing more than one time is that most participants felt pain or discomfort in the previous 12 months and needed dental care but could not get it. Armfield et al found that more frequent dental visiting and toothbrushing were associated with poorer self-rated oral health, more untreated decay, and higher DMFT (i.e. Decayed, Missed, and Filled Teeth). ${ }^{20}$ These factors could have contributed to the difference noticed between those who brushed one or two times and those who brushed more than two times (10\%). In addition, most participants were not smokers, which also supported the high percentage of having a good condition of the gums or teeth.

Acculturation has a huge impact on oral health status, behaviors, and access to care, ${ }^{14,15,25}$ which explains the significant association of poor oral health practices and lower access with care in participants who moved to the United States 1 to 2 or 2 to 5 years ago. A systematic review by Gao and McGrath showed that the higher the acculturation, better are the oral health outcomes, including oral health condition, practices, and utilization of care. The two important domains used in most studies to measure acculturation were time since the refugees moved to the United States and whether they had English-speaking abilities. ${ }^{24}$

Refugees receive medical coverage in the first 8 months after arriving in the United States, ${ }^{28}$ which may enable them to receive dental care. Once coverage is no longer available, they may start facing difficulties accessing medical and dental care. This might explain why $90 \%$ of participants in this study reported the main reason for not receiving dental care was lack of insurance or ability to pay. ${ }^{29}$ Although demographic information of participants is expected to be significantly associated with "access to dental care when needed," the lack of a significant association may be due to the small sample size with almost all of individuals having relatively similar socioeconomic status.

\section{Strengths and Limitations of the Study}

This study provides an insight into the oral health practices and self-reported oral health status of refugees living in San Antonio, identifying barriers to care and dietary behaviors toward which educational efforts can be targeted. 
Table 5 Relationship of demographic data with time since the last visit to a dentist and the main reason for that visit

\begin{tabular}{|c|c|c|c|}
\hline \multicolumn{4}{|l|}{ Time since the last visit to the dentist } \\
\hline & OR & $p$-Value ${ }^{a}$ & $\mathrm{Cl}(95 \%)$ \\
\hline \multicolumn{4}{|l|}{ Less than a year ago } \\
\hline Arabic & 4.37 & 0.03 & $(1.15-16.56)$ \\
\hline Other languages & 1 & & \\
\hline \multicolumn{4}{|l|}{$1-2$ y ago } \\
\hline Persian/Dari & 0.13 & 0.005 & $(0.032-0.532)$ \\
\hline Other languages & 1 & & \\
\hline Younger than 30 y old & 0.22 & 0.05 & $(0.048-0.99)$ \\
\hline 50 y or older & 1 & & \\
\hline \multicolumn{4}{|l|}{$2-5$ y ago } \\
\hline Younger than 30 years old & 0.067 & 0.035 & $(0.006-0.824)$ \\
\hline 50 y or older & 1 & & \\
\hline Moved to the US less than a year ago & 0.39 & 0.02 & $(0.002-0.539)$ \\
\hline Moved to the US $1-2 \mathrm{y}$ ago & NS & NS & NS \\
\hline Moved to the US $2-5$ y ago & 0.106 & 0.043 & $(0.012-0.929)$ \\
\hline Moved to the US more than $5 \mathrm{y}$ ago & 1 & & \\
\hline Less than high school & 0.05 & 0.05 & $(0.002-0.99)$ \\
\hline High school diploma or GED & NS & & \\
\hline Some college & NS & & \\
\hline College degree or higher & 1 & & \\
\hline \multicolumn{4}{|l|}{ Reasons for the last visit } \\
\hline & OR & $p$-Value ${ }^{a}$ & $\mathrm{Cl}(95 \%)$ \\
\hline \multicolumn{4}{|c|}{ Pain or trouble in the mouth, teeth, or gums } \\
\hline Moved to the US 1-2 y ago & 3.47 & 0.034 & $(1.1-10.95)$ \\
\hline Moved to the US more than $5 \mathrm{y}$ ago & 1 & & \\
\hline \multicolumn{4}{|l|}{ Regular checkup or consultation } \\
\hline Moved to the US $1-2 \mathrm{y}$ ago & 0.018 & 0.009 & $(0.001-0.374)$ \\
\hline Moved to the US $2-5$ y ago & 0.062 & 0.015 & $(0.007-0.584)$ \\
\hline Moved to the US more than $5 \mathrm{y}$ ago & 1 & & \\
\hline Less than high school & 0.01 & 0.016 & $(0.00-0.427)$ \\
\hline High school Diploma or GED & 0.114 & 0.038 & $(0.015-0.886)$ \\
\hline College education or higher & 1 & & \\
\hline
\end{tabular}

Abbreviations: $\mathrm{Cl}$, confidence interval; GED, general education diploma; NS, not specified; OR, odds ratio; US, United States.

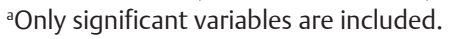

"More than 5 years ago" is the reference category for "time since the last visit to the dentist."

There are limitations in this study. Clinical examination of refugees is critical in determining their oral health status and oral health needs. However, due to limited resources, this project was not able to obtain clinical data through direct examination of refugees.

The self-reported questionnaire is affected by social and cultural desirability, especially for those participants who came from completely different backgrounds. In addition, this was a convenience sample that is not representative of the target population who were war-affected refugees living in San Antonio, which impacts the generalizability to a larger population. A possible bias in sampling is that participants were mostly from the refugee center, where refugees go to receive aid. This restricts the sample to be from refugees who had a low socioeconomic status (SES) and not those of a high SES. In addition, illiterates were excluded, who could have different oral health status and practices compared with others who were able to read any of the languages provided. Another limitation is subjects' recruitment. Encouraging refugees to participate was challenging especially when no monetary incentives were provided. 
Table 6 Relationship of demographic data with dietary and smoking habits

\begin{tabular}{|c|c|c|c|}
\hline \multicolumn{4}{|c|}{ Eating or drinking in the last 24 hours+ } \\
\hline & OR & $p$-Value ${ }^{a}$ & $\mathrm{Cl}(95 \%)$ \\
\hline \multicolumn{4}{|l|}{ Sweets and sugary food } \\
\hline $18-29$ y old & 6.4 & 0.003 & $(1.86-21.97)$ \\
\hline 50 y or older & 1 & & \\
\hline \multicolumn{4}{|l|}{ Sodas (coke, sprite, etc.) } \\
\hline Moved to US 1-2 y ago & 0.24 & 0.047 & $(0.059-0.981)$ \\
\hline Moved to US more than $5 \mathrm{y}$ ago & 1 & & \\
\hline $18-29$ y old & 3.32 & 0.04 & $(1.06-10.42)$ \\
\hline 50 y or older & 1 & & \\
\hline \multicolumn{4}{|l|}{ Other sugar-sweetened beverages } \\
\hline Male & 0.46 & 0.048 & $(0.22-0.92)$ \\
\hline Female & 1 & & \\
\hline Arabic & 7.49 & 0.005 & $(1.84-30.51)$ \\
\hline Rohingya & 10.11 & 0.012 & $(1.65-62.02)$ \\
\hline Other languages & 1 & & \\
\hline \multicolumn{4}{|l|}{ Two or more servings of fruit } \\
\hline Moved to US less than a year ago & 0.236 & 0.017 & $(0.072-0.769)$ \\
\hline Moved to US 1-2 y ago & NS & NS & NS \\
\hline Moved to US 2-5 y ago & 0.145 & 0.001 & $(0.046-0.461)$ \\
\hline Moved to US 5 y or more ago & 1 & & \\
\hline \multicolumn{4}{|l|}{ Tobacco use } \\
\hline \multicolumn{4}{|l|}{ Often } \\
\hline Male & 12.45 & 0.003 & $(2.38-65.1)$ \\
\hline Female & 1 & & \\
\hline Less than high school & 6.97 & 0.02 & $(1.36-35.8)$ \\
\hline College degree or higher & 1 & & \\
\hline Arabic & 6.88 & 0.021 & $(1.33-35.54)$ \\
\hline Other languages & 1 & & \\
\hline
\end{tabular}

Abbreviations: $\mathrm{Cl}$, confidence interval; NS, not specified; OR, odds ratio; US, United States.

anly significant variables are included.

"Never or rarely used tobacco" is the reference group for tobacco use.

\section{Conclusions}

Although most refugees participated in this study reported good teeth and gum condition, they encountered pain the previous 12 months that needed dental care but couldn't get because they lacked dental coverage, or they were not able to pay. Improving oral health access for refugees will help to improve their oral and general health and prevent oral diseases and other diseases related to oral health. However, good access to care that includes cultural and language feasibility is essential to provide the quality of care refugees need. ${ }^{30}$

In addition, refugees manifested acceptable brushing habits, but their eating and drinking habits were inadequate. Therefore, refugees do not only need dental care provision but dental education as well, which will prevent them from oral diseases and improve their overall quality of life. ${ }^{31}$

\section{Ethical Approval}

This study obtained approval from the institutional review board of the University of Texas Health Science Center at San Antonio. Participants were informed about the purpose of the study and their completion of the questionnaire was considered a consent to participate.

Funding

None.

\section{Conflict of Interest}

None declared.

\section{Acknowledgments}

We would like to thank the San Antonio Center for Refugee Services for their outstanding cooperation and for allowing to collect data at their site. 


\section{References}

1 Texas Department of State Health Services, 2015 Refugee Health Report. In: Texas Refugee Health Program, ed; 2015 Available at: http://www.dshs.texas.gov/idcu/health/refugee_health/statistics.

2 Pew Research Center. U.S. admits record number of Muslim refugees in 2016. 2016. Available at: http://www.pewresearch. org/fact-tank/2016/10/05/u-s-admits-record-number-ofmuslim-refugees-in-2016/. Accessed March 20, 2020

3 Cote S, Geltman P, Nunn M, Lituri K, Henshaw M, Garcia RI. Dental caries of refugee children compared with US children. Pediatrics 2004;114(6):e733-e740

4 Texas Tribune. Syrians Small Fraction of Refugees Reaching Texas. 2015. Available at: www.texastribune.org/2015/12/08/ where-refugees-living-texas-are/. Accessed March 20, 2020.

5 Ackerman LK. Health problems of refugees. J Am Board Fam Pract 1997; 10(5):337-348

6 Hayes EB, Talbot SB, Matheson ES, Pressler HM, Hanna AB, McCarthy CA. Health status of pediatric refugees in Portland, ME. Arch Pediatr Adolesc Med 1998;152(6):564-568

7 Hollifield M, Warner TD, Lian N, et al. Measuring trauma and health status in refugees: a critical review. JAMA 2002;288(5):611-621

8 Meropol SB. Health status of pediatric refugees in Buffalo, NY. Arch Pediatr Adolesc Med 1995;149(8):887-892

9 Solyman M, Schmidt-Westhausen AM. Oral health status among newly arrived refugees in Germany: a cross-sectional study. BMC Oral Health 2018;18(1):132-132

10 World Health Organization (W.H.O). Caries status in Europe and predictions of future trends. Caries Res 1990;24(6):381-396

11 Zimmerman M. Oral health in groups of refugees in Sweden. Swed Dent J Suppl 1993;94:1-40

12 Angelillo IF, Nobile CG, Pavia M. Oral health status and treatment needs in immigrants and refugees in Italy. Eur J Epidemiol 1996;12(4):359-365

13 Kalsbeek H, Zijlstra-Remon N, Filedt Kok-Weimar TL. [Oral health and dental care in refugee children]. Ned Tijdschr Tandheelkd 2001;108(10):404-407

14 Geltman PL, Adams JH, Cochran J, et al. The impact of functional health literacy and acculturation on the oral health status of Somali refugees living in Massachusetts. Am J Public Health 2013;103(8):1516-1523

15 Geltman PL, Hunter Adams J, Penrose KL, et al. Health literacy, acculturation, and the use of preventive oral health care by Somali refugees living in Massachusetts. J Immigr Minor Health 2014;16(4):622-630

16 World Health Organization, Oral Health Surveys: Basic Methods. 5th edition. 2013
17 Sabbah W, Tsakos G, Chandola T, Sheiham A, Watt RG. Social gradients in oral and general health. J Dent Res 2007;86(10):992-996

18 Turrell G, Sanders AE, Slade GD, Spencer AJ, Marcenes W. The independent contribution of neighborhood disadvantage and individual-level socioeconomic position to self-reported oral health: a multilevel analysis. Community Dent Oral Epidemiol 2007;35(3):195-206

19 Finlayson TL, Williams DR, Siefert K, Jackson JS, NowjackRaymer R. Oral health disparities and psychosocial correlates of self-rated oral health in the National Survey of American Life. Am J Public Health 2010;100(Suppl 1) :S246-S255

20 Armfield JM, Mejía GC, Jamieson LM. Socioeconomic and psychosocial correlates of oral health. Int Dent J 2013;63(4):202-209

21 Guarnizo-Herreño CC, Watt RG, Pikhart H, Sheiham A, Tsakos G. Socioeconomic inequalities in oral health in different European welfare state regimes. J Epidemiol Community Health 2013;67(9):728-735

22 Luchi CA, Peres KG, Bastos JL, Peres MA. Inequalities in self-rated oral health in adults. Rev Saude Publica 2013;47(4):740-751

23 Eke PI, Thornton-Evans GO, Wei L, Borgnakke WS, Dye BA, Genco RJ. Periodontitis in US Adults: National Health and Nutrition Examination Survey 2009-2014. J Am Dent Assoc 2018;149(7):576-588.e6

24 Gao XL, McGrath C. A review on the oral health impacts of acculturation. J Immigr Minor Health 2011;13(2):202-213

25 Cruz GD, Chen Y, Salazar CR, Le Geros RZ. The association of immigration and acculturation attributes with oral health among immigrants in New York City. Am J Public Health 2009;99(Suppl 2) :S474-S480

26 WorldHealthOrganization(W.H.O),10FactsonGenderandTobacco. Geneva, Switzerland 2010. Available from: http://www.who.int/ gender/documents/10facts_gender_tobacco_en.pdf?ua=1.

27 American Lung Association. Women and Tobacco Use 2018. Available at: http://www.lung.org/stop-smoking/smokingfacts/women-and-tobacco-use.html

28 U.S Department of Health \& Human Services. Health Insurance 2015. Available at: https://www.acf.hhs.gov/orr/health

29 Bayat F, Vehkalahti MM, Zafarmand AH, Tala H. Impact of insurance scheme on adults' dental check-ups in a developing oral health care system. Eur J Dent 2008;2(1):3-10

30 Keboa MT, Hiles N, Macdonald ME. The oral health of refugees and asylum seekers: a scoping review. Global Health 2016;12(1):59

31 Abu-Awwad M, Al-Omoush S, Shqaidef A, Hilal N, Hassona Y. Oral health-related quality of life among Syrian refugees in Jordan: a cross-sectional study. Int Dent J 2020;70(1):45-52 